Email: jkesislam@unisma.ac.id

Home Page : http://riset.unisma.ac.id/index.php/jki

\title{
Efek Saffron (Crocus sativus) Terhadap TNF-a Pada Model Artritis Reumatoid
}

\author{
$\underline{\text { Karina Dwiyanti }}{ }^{1}$, Hotimah Masdan Salim ${ }^{2}$
}

${ }^{1}$ Faculty of Medicine, University of Nahdlatul Ulama Surabaya.

${ }^{2}$ Department Medical Biochemistry, Faculty of Medicine, University of Nahdlatul Ulama

Surabaya.

karindwiyanti5@gmail.com

\begin{abstract}
ABSTRAK
Artritis Reumatoid (AR) merupakan penyakit autoimun yang mempengaruhi sendi yang dapat menyebabkan kerusakan sendi yang progresif dan deformitas. Pada penyakit peradangan kronis ini terdapat banyak sitokin inflamasi yang salah satunya adalah TNF- $\alpha$ yang merupakan sitokin utama yang berlimpah dalam sinovium yang sedang meradang. Saffron dikenal karena sifat antioksidannya yang kuat dan sifat anti peradangan. Kemampuan pengambilan radikal pada saffron berhubungan dengan kemampuannya sebagai anti inflamasi yang dapat memblokir produksi sitokin pro-inflamasi seperti TNF- $\alpha$. Penelitian ini bertujuan untuk merangkum peran saffron (Crocus sativus) dan konstituennya terhadap TNF- $\alpha$ pada model artritis reumatoid. Pencarian literatur dilakukan dengan menggunakan database PubMed Central dengan hasil screening didapatkan empat jurnal yang memenuhi kriteria inklusi. Pada hasil analisis telaah jurnal pada penelitian ini didapatkan bahwa literatur ilmiah mengkonfirmasi peran saffron (Crocus sativus) dalam menurunkan kadar TNF- $\alpha$ pada model artritis reumatoid.
\end{abstract}

Kata Kunci: Saffron, Crocus saticus, crocin, crocetin, saffranal, TNF- $\alpha$, Artritis Reumatoid

\begin{abstract}
Rheumatoid arthritis (RA) is an autoimmune disease that affects joints which can cause progressive joint damage and deformity. In this chronic inflammatory disease, there are many inflammatory cytokines, such as TNF- $\alpha$ which is the main cytokine added to the synovium that is inflamed. Saffron is known for its strong antioxidant and antiinflammatory properties. The ability to pick up radicals in safety is related to its ability as an anti-inflammatory which can help to block pro-inflammatory cytokines such as TNF- $\alpha$. This study aims to summarize the role of saffron (Crocus sativus) and its constituents on TNF- $\alpha$ in rheumatoid arthritis models. A literature search was performed using the PubMed Central database with the screening results obtained 4 journals that met the inclusion criteria. The journal analysis results in this study has indicated that scientific literature confirms the role of saffron (Crocus sativus) in reducing TNF- $\alpha$ levels in rheumatoid arthritis models.
\end{abstract}

Keywords: Saffron, Crocus sativus, crocin, crocetin, saffron, TNF- $\alpha$, Rheumatoid Arthritis

\section{PENDAHULUAN}

Artritis Reumatoid (AR) adalah suatu penyakit peradangan kronis yang merupakan penyakit autoimun yang terutama mempengaruhi sendi dan menyebabkan rasa sakit, kelelahan dan gangguan fungsi. Pada umumnya, penyakit ini memiliki gejala klinis yang ditandai dengan pembengkakan polyarticular persisten yang tidak menular terutama pada sendi kecil yang mengarah ke erosi tulang dan kerusakan sendi yang progresif dan adanya deformitas (1).

Artritis Reumatoid (AR) mempengaruhi sekitar 1\% populasi dan ditandai dengan radang sendi kronis yang dapat menimbulkan kecacatan dan meningkatkan mortalitas dan morbiditas (2). Menurut Artritis Foundation (2015) terdapat 22\% atau lebih dari 50 juta orang dewasa di Amerika Serikat berusia 18 tahun atau lebih didiagnosa artritis dan sekitar 3\% atau 1,5 juta orang dewasa mengalami AR dan untuk populasi orang dewasa di negara maju terjadi sekitar $0,5-1 \%$ (3).

Pada tahun 2010 menurut WHO mengatakan bahwa terdapat lebih dari 355 juta orang di dunia menderita Artritis Reumatoid (AR) atau dapat dikatakan bahwa pada setiap 6 orang, 1 diantaranya mengidap artritis reumatoid dengan perbandingan pasien wanita tiga kali lebih banyak dari pria dan diperkirakan akan terus meningkat hingga tahun 2025 dengan indikasi lebih dari 25\% akan mengalami kelumpuhan (4). Dengan tingkat prevelensi AR pada negara berpenghasilan rendah atau menengah adalah $0,40 \%$ untuk Asia Tenggera, $0,37 \%$ untuk Mediterania Timur, $0,62 \%$ unutk Eropa, 1,25\% untuk Amerika dan 0,42\% untuk wilayah pasifik barat (5). 
Di Indonesia, terdapat 23,3\% - 31,5\% dari jumlah penduduk Indonesia yang mendertia AR. Dan prevelensi AR menurut hasil penelitian yang dilakukan oleh Nainggolan (2010), jumlah penderita AR di Indonesia tahun 2009 tercatat adalah $23,6 \%$ sampai $31,3 \%$ (3).

Pada penyakit peradangan kronis ini terdapat banyak sitokin inflamasi yang telah diakui berperan dalam patogenesis penyakit AR. TNF- $\alpha$ dan IL- $1 \beta$ adalah sitokin utama yang berlimpah dalam sinovium yang sedang meradang. Ekspresi TNF- $\alpha$ yang tidak teratur pada artritis eksperimental telah dilaporkan menyebabkan artritis destruktif (6).

Pengobatan pada AR yang umum digunakan adalah Disease Modifying Anti Rheumatic (DMARDs) sebagai imun supresif, kortikosteroid, dan klorokuin dengan cara kerja memperlambat perkembangan penyakit, pengubah respon biologis untuk mengurangi peradangan, kerusakan struktural sendi, dan obat anti inflamasi yang jika terus dilakukan dalam jangka waktu yang lama akan menimbulkan efek samping yaitu reaksi hipersensitivitas, gangguan fungsi hati dan ginjal, serta penekanan sistem hematopoetik. Sehingga saat ini tanaman herbal telah dianggap sebagai pengobatan yang penting untuk pendekatan kesehatan dengan tingkat efek samping yang lebih rendah dan menurut laporan global WHO, penggunaan herbal telah dipergunakan secara luas sebagai obat-obatan di seluruh dunia. Saffron, sebagai rempah terkenal yang diekstrak dari bunga Crocus sativus L. telah digunakan secara tradisional untuk mengobati berbagai penyakit termasuk depresi, penyakit kardiovaskular gangguan menstruasi, asma, insomnia, penyakit pencernaan, dan beberapa lainnya (7).

Efek menguntungkan dari saffron, adalah karena sejumlah bahan yang terkandung di dalam rempah rempah ini termasuk, safranal, crocetin, dan crocin. Terdapat studi eksperimental tahun 2015 oleh Rathore et al pada model mencit Atritis Reumatoid dengan menunjukkan bahwa saffron pada dosis $100 \mathrm{mg} / \mathrm{KgBB}$ dapat dibandingkan dengan ASA (Acetyl Salicylic Acid) dalam mengatasi inflamasi pada Artritis Reumatoid akibat antioksidan kuat yang dapat memberikan perlindungan yang luas terhadap sitokin inflamasi dan gangguan oksidatif (6).

Pada penelitian lainnya oleh Li, Jiang dan Zhu tahun 2017 yang menganalisis efek terapeutik dari model tikus Artritis Reumatoid (AR) dengan mengevaluasi tingkat pembengkakan jari kaki, skor artritis, ekspresi iNOS dalam sinovium artritis, dan indeks timus dan spleen dengan hasil yang menunjukkan bahwa crocin pada saffron dapat meringankan pembengkakan pada kaki yang diinduksi artritis, menurunkan skor artritis, menurunkan ekspresi iNOS pada sinovial artritis pada tikus, dan mengurangi indeks dari thymus (8). Maupun penelitian dari Liu et al., pada tahun 2018, yang juga menemukan bahwa crocin pada kandungan saffron dapat menurunkan skor artritis, pembengkakan pada kaki mencit, dan menurunkan berat badan dari tikus yang diinduksi artritis. Penelitian ini juga menemukan bahwa crocin pada saffron dapat menurunkan inflamasi, kematian kondrosit, permukaan erosi pada cartilage, erosi tulang, kadar serum TNF- $\alpha$, IL-17, IL-6 dan menurunkan regulasi ekspresi mRNA dari sitokin pro inflamasi pada tikus yang diinduksi kolagen artritis (Liu et al., 2018).

\section{METODE}

Metode yang digunakan pada penelitian ini adalah Systematic Literature Review (SLR) yang merupakan metode yang digunakan untuk melakukan identifikasi, evaluasi dan interpretasi terhadap hasil penelitian yang berkaitan dengan topik tertentu dengan menggunakan studi sekunder untuk kemudian dilakukan sintesis dari berbagai hasil penelitian yang relevan dan menghasilkan fakta yang akan disajikan menjadi lebih komprehensif dan berimbang (10).

Data sekunder yang digunakan dalam penelitian ini didapat melalui database PubMed Central dengan kata kunci yaitu "saffron on tnf on arthritis". Data difokuskan dengan melakukan screening berdasarkan kriteria inklusi, yaitu: 1) Jurnal internasional yang berkaitan dengan efek saffron, 2) Jurnal internasional yang berkaitan dengan artritis reumatoid, 3) Jurnal yang membahas TNF- $\alpha$ pada artritis reumatoid, 4) Jurnal diterbitkan dalam rentang waktu 10 tahun, 5) Tipe jurnal berupa review article dan research article, 6) Jurnal dapat diakses secara penuh.

Pencarian artikel pada database PubMed Central hingga 4 Agustus 2020 didapatkan total 192 jurnal internasional yang kemudian tidak ditemukan adanya duplikasi pada 192 jurnal tersebut melalui aplikasi Mendeley sehingga jurnal dilanjutkan dengan melakukan screening pada judul dan abstrak dan didapatkan 33 jurnal. Kemudian jurnal dilakukan penilaian berdasarkan kelayakan dan didapatkan 4 jurnal telah memenuhi kelayakan dan siap untuk dilakukan analisis lebih lanjut.

\section{HASIL DAN ANALISA DATA}

Ringkasan literature review pada 4 artikel tentang efek saffron terhadap TNF- $\alpha$ pada model artritis reumatoid ditampilkan melalui matrik analisa (Tabel 1). Hasil ringkasan didapatkan bahwa saffron 
Tabel 1. Matrik analisa data pada artikel yang digunakan dalam literature review

\begin{tabular}{|c|c|c|c|}
\hline Peneliti, Judul, Jurnal & Tujuan & Sampel (kriteria), Instrumen & Hasil \\
\hline $\begin{array}{l}\text { - Wei Liu, Yufeng Sun, Zhenping } \\
\text { Cheng, Yong Guo, Peiming Liu, } \\
\text { dan Ying Wen } \\
\text { - Crocin exerts anti-inflammatory } \\
\text { and anti-arthritic effects on type } \\
\text { II collagen-induced arthritis in } \\
\text { rats (2018) } \\
\text { - Pharmaceutical Biology, } 2018 \\
\text { Vol. 56, No. 1, 209-216 }\end{array}$ & $\begin{array}{l}\text { Menginvestigasi efek } \\
\text { anti-inflamasi dan } \\
\text { anti-artritis dari crocin } \\
\text { pada artritis yang } \\
\text { diinduksi kolagen tipe } \\
\text { II pada tikus wistar }\end{array}$ & $\begin{array}{ll}- & \text { Tikus Type II Collagen-Induced } \\
\text { Arthritis (CIA) atau tikus yang } \\
\text { diinduksi dengan collagen tipe II } \\
\text { - } & \text { ELISA }\end{array}$ & $\begin{array}{l}\text { Tikus CIA (Collagen Induced } \\
\text { Arthritis) yang menerima dosis } \\
\text { tertinggi ( } 40 \mathrm{mg} / \mathrm{kg}, P<0.01 \text { ) } \\
\text { crocin menunjukkan kadar } \\
\text { sitokin pro-inflamasi (termasuk } \\
\text { TNF- } \alpha \text { ) serum terendah, } \\
\text { dibandingkan dengan } \\
\text { kelompok eksperimen dosis } \\
\text { lainnya (Liu et al., 2018). }\end{array}$ \\
\hline $\begin{array}{l}\text { - Majid Zeinali, Mohammad Reza } \\
\text { Zirak, Sayed Abdolrahim } \\
\text { Rezaee, Gholamreza Karimi, dan } \\
\text { Hossein Hosseinzadeh } \\
\text { - Immunoregulatory and anti- } \\
\text { inflammatory properties of } \\
\text { Crocus sativus (Saffron) and its } \\
\text { main active constituents : A } \\
\text { review (2019) } \\
\text { - Iran J Basic Med Sci, Vol. 22, } \\
\text { No. } 4\end{array}$ & $\begin{array}{l}\text { Merangkum peran } \\
\text { protektif Crocus } \\
\text { sativus dan } \\
\text { konstituensnya } \\
\text { terhadap patogenesis } \\
\text { dari penyakit imun. }\end{array}$ & $\begin{array}{l}\text { - Sampel menggunakan literatur } \\
\text { dengan masalah utama } \\
\text { mengidentifikasi efek } \\
\text { imunomodulator Crocus sativus } \\
\text { (saffron) dan konstituen aktifnya } \\
\text { khususnya crocin, crocetin, dan } \\
\text { safranal dengan bukti eksperimental } \\
\text { keterlibatan dalam sistem kekebalan } \\
\text { tubuh dengan menggunakan kata } \\
\text { kunci: "Crocus sativus", "saffron”, } \\
\text { "crocin". "crocetin", } \\
\text { "picrocrocin", "safranal”, } \\
\text { "cytokines", "innate immunity”, } \\
\text { "adaptive immunity”, dan "immune } \\
\text { system” } \\
\text { Database SciVerse (Science Direct } \\
\text { and Scopus), PubMed, } \\
\text { SpringerLink, Wiley Online Library, } \\
\text { dan Google scholar }\end{array}$ & $\begin{array}{l}\text { Penelitian oleh Hemshekhar et } \\
\text { al., menyatakan bahwa crocin } \\
\text { dengan dosis } 10 \text { dan } 20 \mathrm{mg} / \mathrm{Kg} \\
\text { sejak hari ke } 11 \text { sampai hari ke } \\
25 \text { per oral memberikan efek } \\
\text { modulasi pada mediator } \\
\text { inflamasi salah satunya TNF- } \alpha \\
\text { secara efektiv (P<0.05) } \\
\text { dibandingkan dengan hewan } \\
\text { artritis (Zeinali et al., 2019). }\end{array}$ \\
\hline $\begin{array}{l}\text { - Yi Li, Rajat Kakkar, dan Jian } \\
\text { Wang } \\
\text { - In vivo and invitro approach to } \\
\text { anti-arthritic and anti- } \\
\text { inflammatory of nuclear factor- } \\
\text { E2-related factor } 2 / \text { hem } \\
\text { oxygenase }(H O) \text { - and NF-kB } \\
\text { (2018) } \\
\text { - Frontiers in Pharmacology, } \\
\text { volume 9, article } 1341\end{array}$ & $\begin{array}{l}\text { Untuk meneliti efek } \\
\text { anti-inflamasi dari } \\
\text { crocetin menggunakan } \\
\text { makrofag tikus (RAW } \\
\text { 264.7) yang diinduksi } \\
\text { lipo polysaccharide } \\
\text { (LPS) secara in vitro } \\
\text { dan untuk } \\
\text { mengeksplorasi } \\
\text { mekanisme aksi yang } \\
\text { mungkin terjadi secara } \\
\text { in vivo dengan } \\
\text { menggunakan model } \\
\text { artritis yang diinduksi } \\
\text { CFA (Complete } \\
\text { Freund Adjuvant) }\end{array}$ & $\begin{array}{l}\text { - Tikus wistar swiss albino (100-125 } \\
\text { g) yang diinduksi CFA model artritis } \\
\text { kronis dan makrofag RAW 267,4 } \\
\text { yang diinsuksi LPS. } \\
\text { Kultur sel dengan supernatan dengan } \\
\text { kit yang sesuai (Perpro Tech Inc., } \\
\text { Rocky Hill, NJ, Amerika Serikat) }\end{array}$ & $\begin{array}{l}\text { Crocetin }(100 \mu \mathrm{g} / \mathrm{mL}) \text { secara } \\
\text { signifikan }(\mathrm{P}<0,001) \\
\text { menurunkan tingkat TNF- } \alpha \pm \\
936 \mathrm{pg} / \mathrm{mL})(15) .\end{array}$ \\
\hline $\begin{array}{l}\text { - Jin-Feng Wang, Hai-Jun Xu, } \\
\text { Zhao-Long He, Qin Yin, dan Wei } \\
\text { Cheng } \\
\text { - Crocin alleviates pain } \\
\text { hyperalgesia in AIA rats by } \\
\text { inhibiting the spinal Wnt5a/ } \beta \text { - } \\
\text { Catenin signaling pathway and } \\
\text { glial activation (2020) } \\
\text { - Hindawi Neural Plasticity } \\
\text { Volume } 2020\end{array}$ & $\begin{array}{l}\text { Untuk menyelidiki } \\
\text { efek crocin pada nyeri } \\
\text { AIA (Adjuvant } \\
\text { Induced Arthritis) dan } \\
\text { hubungannya dengan } \\
\text { Wnt5a/ } \beta \text {-Catenin dan } \\
\text { faktor yang berperan } \\
\text { didalamnya. }\end{array}$ & $\begin{array}{ll}- & \text { Tikus adjuvant-induced arthritis } \\
& \text { (AIA) } \\
\text { - } & \text { ELISA }\end{array}$ & $\begin{array}{l}\text { Hasil ELISA menunjukkan } \\
\text { bahwa crocin dapat secara } \\
\text { signifikan menurunkan kadar } \\
\text { dari TNF- } \alpha(P<0.05) \text { pada sum } \\
\text { sum tulang belakang model } \\
\text { tikus AIA (adjuvant induced } \\
\text { arthritis)(16) }\end{array}$ \\
\hline
\end{tabular}

memiliki efek dalam menurunkan kadar TNF- $\alpha$ yang dimodulasi oleh berbagai kandungan didalamnya seperti crocin dan crocetin. Hasil yang ditunjukkan oleh Liu et al. (2018) menunjukkan bahwa kandungan crocin yang terdapat dalam saffron dapat memberikan efek dalam menurunkan kadar TNF- $\alpha$ yang juga sejalan dengan penelitian oleh Zeinali et al. (2019) yang menyampaikan hasil penelitian oleh Hemshekhar et al dan Wang et al. (2020) yang juga menemukan efek dari crocin dalam menurunkan TNF- $\alpha$ secara signifikan. Sedangkan itu, pada penelitian lainnya oleh Li et al. (2018) menunjukkan bahwa senyawa lain yang terkandung dalam saffron yakni crocetin juga memiliki kemampuan secara signifikan dalam menurunkan tingkat TNF- $\alpha$.

\section{Karateristik Studi yang Dianalisis}

\section{Mekanisme kerja saffron terhadap TNF- $\alpha$}

Kemampuan modulasi imunitas pada saffron yang salah satunya berperan dalam memodulasi sitokin pro-inflamasi (IL-1 $\beta$, IL-6, TNF- $\alpha$ ) dan efek 
terapeutik lainnya sebagian besar adalah karena keberadaan konstituen saffron yang memiliki kemampuan pengambilan radikal bebas (radical scavenging) yang kuat. Konstituen utama yang terlibat dalam memberikan fungsi biologi dari saffron termasuk saffranal, pirocrocin, crocetin, crocin dan apocarotenoid (11).

Beberapa penelitian telah menunjukkan peran konstituen yang terkandung dalam saffron dalam mengurangi inflamasi pada beberapa model salah satunya artritis reumatoid. Penelitian oleh Liu et al., (2018) menjelaskan bahwa konstituen saffron yakni crocin dapat menuurunkan TNF- $\alpha$ dengan melakukan penghambatan terhadap mRNA dari sitokin proinflamasi (Liu et al., 2018).

Penelitian lainnya oleh Zeinali et al. (2019) yang menyampaikan hasil penelitian oleh Hemshekhar et al., (2012) yang meneliti mengenai konstituen crocin pada saffron menemukan bahwa crocin memiliki kemampuan dalam menurunkan TNF- $\alpha$ melalui mekanisme menghambat HAase. Pada artritis, HAase akan meningkat yang akan menyebabkan degradasi dari komponen extracellular matrix (ECM) yang yakni termasuk didalamnya adalah type II collagen, hyaluronan (HA), dan aggrecan. Peningkatan HAase tersebut yang menghasilkan terjadinya degenerasi articular cartilage yang berat. Degradasi HA yang terjadi akibat HAase kemudian akan menginduksi kondrosit artikular dan fibroblas kartilage untuk mensekresi sitokin proinflamasi yakni salah satunya TNF- $\alpha$. Sehingga penghambatan HAase oleh crocin tidak hanya akan mengurangi degradasi HA tetapi juga akan mengurangi pelepasan sitokin inflamasi (12).

Selanjutnya, penelitian oleh Li, Kakkar dan Wang (2018) mendapatkan bahwa yang berpengaruh dalam menurunkan TNF- $\alpha$ pada model artritis adalah crocetin. Hal tersebut terjadi melalui penghambatan ekspresi NF-Kappa B yang merupakan faktor transkripsi yang memainkan peran yang signifikan dalam degradasi sendi dan inflamasi dengan cara meningkatkan ekspresi dari gen pro-inflamasi seperti IL-6, IL- $1 \beta$, TNF- $\alpha$, MMPs, dan kemokin.

Contoh lainnya yang dapat menjelaskan mekanisme penurunan TNF- $\alpha$ pada artritis dijelaskan dalam penelitian oleh Wang et al. (2020) yang menjelaskan mengenai mekanisme lainnya yang terjadi dalam menurunkan TNF- $\alpha$ pada model artritis reumatoid melalui penghambatan $\mathrm{Wnt} 5 \mathrm{a} / \beta$. Jalur Wnt5a/ $\beta$-catenin adalah jalur sinyal klasik dari Wnt yang dapat mempengaruhi proses dan prognosis dari RA dengan cara mempengaruhi fibroblast-like synoviocytes dan meregulasi sekresi dari faktor inflamasi dan metabolisme tulang/destruksi tulang. Terdapat bukti yang menyatakan bahwa Wnt5a pada sum sum tulang belakang mungkin berperan penting dalam regulasi nyeri kronik dan artritis reumatoid. Aktifasi dari jalur sinyal Wnt dapat menstimulasi produksi dari faktor inflamasi TNF- $\alpha$ dan IL-1 $\beta$ dan dapat menyebabkan perburukan dari nyeri neuropati.

\section{P-Value artikel terkait efek saffron terhadap TNF-a}

P-value atau nilai $\mathrm{p}$ merupakan nilai yang menunjukkan besarnya peluang salah menolak $\mathrm{HO}$ dari data penelitian yang dapat diartikan pula sebagai nilai besarnya peluang hasil penelitian terjadi karena faktor kebetulan dengan harapan bahwa nilai $\mathrm{p}$ adalah sekecil mungkin, sebab nilai $\mathrm{p}$ yang kecil maka menyatakan bahwa perbedaan yang ada pada penelitian terjadi bukan karena faktor kebetulan (by chance). Ketentuan yang berlaku pada nilai $\mathrm{p}$ adalah : Bila nilai $\mathrm{p}<$ nilai alpha maka keputusannya adalah H0 ditolak, sedangkan bila nilai $\mathrm{p}>$ nilai alpha maka keputusannya adalah $\mathrm{H} 0$ gagal ditolak (13).

$P$-value pada artikel yang digunakan dalam literature review ini (Diagram 1) antara lain adalah sebagai berikut:

a) Immunoregulatory and anti-inflammatory properties of Crocus sativus (Saffron) and its main active constituents : A review oleh Zeinali et al., 2019 mengenai penelitian oleh Hemshekhar et al. (2012) dengan p-value $\mathrm{p}<0.05$.

b) Crocin exerts anti-inflammatory and antiarthritic effects on type II collagen-induced arthritis in rats oleh Liu et al., 2018, dengan pvalue $\mathrm{p}<0.01$.

c) In vivo and invitro approach to anti-arthritic and anti-inflammatory of nuclear factor-E2related factor 2/hem oxygenase $(\mathrm{HO})$ and $\mathrm{NF}$ kappa B oleh Li, Kakkar dan Wang, 2018, dengan $\mathrm{p}$-value $\mathrm{p}<0.001$.

d) Crocin alleviates pain hyperalgesia in AIA rats by inhibiting the spinal Wnt5a/ $\beta$-Catenin signaling pathway and glial activation oleh Wang et al., 2020, dengan p-value $\mathrm{p}<0.05$.

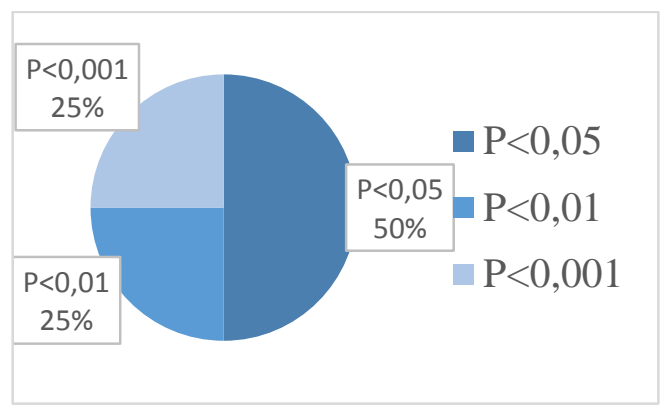

Diagram 1. P-Value artikel literatur review 


\section{PEMBAHASAN}

Artritis Reumatoid (AR) merupakan penyaktit autoimun sistemik yang ditandai dengan adanya inflamasi pada sendi yang bersifat simetris yang kronis dan dapat menyebabkan destruksi pada tulang, kerusakan jaringan, dan disfungsi sendi. Hal tersebut terjadi akibat patogenesis yang mendasari terjadinya penyakit artritis reumatoid yang diperankan oleh sitokin pro-inflamasi seperti TNF$\alpha$, IFN- $\gamma$, IL-1 $\beta$, IL-6, dan IL-17 (Kim dan Moudgil, 2017).

TNF- $\alpha$ berperan terhadap makrofag untuk meningkatkan fagositosis dan juga produksi dari sitokin pro-inflamasi lainnya dan prostaglandin E2 (PGE2). Tak hanya itu, TNF- $\alpha$ juga berperan untuk mejadi chemoattractant bagi neutrofil, dan menginduksi ekspresi kemokin pada sel endotel untuk memfasilitasi migrasi dari neutrofil. TNF- $\alpha$ bekerja pada fibroblast-like synoviocytes (FLS) untuk menginduksi proliferasi dan formasi dari pannus, dan meningkatkan regulasi kolagen dan matrix metalloproteinases (MMPs), yang merupakan salah satu yang berpartisipasi dalam kerusalan kartilage (Kim dan Moudgil, 2017).

Potensi anti-inflamasi yang terdapat pada saffron berkaitan dengan keutamaan dari antioksidan kuat yang dapat mengangkut radikal yang terutama dikaitkan dengan crocetin dan crocin. Beberapa penelitian memperkirakan bahwa aktivitas immunomodulator dari saffron mungkin melibatan penargetan langsung pada Toll-like receptors (TLRs) yang berfungsi untuk melakukan trigger sinyal pro-inflamasi untuk merespon stimulus eksternal maupun internal. Tak hanya itu, aktivitas immunomodulator dari saffron juga dikaitkan dengan regulasi berbagai faktor transkripsi seperti nuclear factor (NF-kappa B) yang berperan penting dalam memproduksi sitokin pro-inflamasi (Zeinali et al., 2019). Hal tersebut juga sesuai dengan penelitian yang dilakukan oleh Li, Kakkar dan Wang, 2018 yang menilai bahwa penurunan TNF- $\alpha$ pada penelitian yang dilakukan, berhubungan dengan kandungan pada saffron yang dapat menghambat ekspresi NF-kappa B yang berperan dalam meregulasi ekspresi gen penting seperti COX2 , iNOS, dan TNF- $\alpha$ (15). Adapun proses penurunan TNF- $\alpha$ melalui penghambatan NF-Kappa B juga dijelaskan dalam penelitian oleh Song et al. (2016) yang membuktikan efek crocetin sebagai antiinflamasi melalui jalur NF-kB. Pada penelitian ini digunakan model sel endotel vena umbilikal dengan menggunaan stimulasi dari lipopolysaccharide (LPS) untuk mengaktifkan I $\mathrm{KB} \alpha$ kinase (IKK) melalui reseptor tumor necrosis factor (TNFR) dan reseptor interleukin-1 (IL-1R) yang selanjutnya memfosforilasi dan memberi sinyal untuk menurunkan sitoplasma I $\mathrm{B} \alpha$ subunit dari kompleks I $\mathrm{B} \alpha-\mathrm{p} 65-\mathrm{p} 50$. Setelah degradasi I $\mathrm{B} \alpha$, subunit p65 dilepaskan dan ditranslokasi ke dalam nukleus, dimana ia mengaktifkan aktivitas translasi gen inflamasi atau sitokin proinflamasi. Crocetin kemudian diobservasi untuk menstabilkan kompleks I $\kappa \alpha$-p65-p50, dan dengan demikian akan menghalangi kaskade persinyalan didalamnya (18). Penelitian serupa mengenai NF-kB juga telah dilakukan dan dibuktikan pada berbagai model lainnya yakni penelitian oleh Li et al. (2017) yang meneliti fungsi crocin dalam melindungi sel podosit terhadap peningkatan gula darah melalui penghambatan NF-kB (19) dan penelitian oleh Amin et al. (2011) yang meneliti sifat anti kanker pada model hepato celullar carcinoma (HCC) melalui penurunan marker infamasi, penurunan proliferasi sel kanker, induksi apoptosis, menurunkan stress oksidatif, dan ekspresi NF-kB (20). Bahkan efek dari crocin dan saffron aquous ethanol (SAE) dilaporkan telah di uji coba secara klinis kepada manusia melalui penelitian oleh Abedimanesh et al. (2019) pada pasien dengan penyakit arteri koroner yang memberikan hasil bahwa crocin dan SAE mampu menurunkan ekspresi NF-kB dan dinilai memiliki peran yang penting dalam aterosklerosis (21).

Selanjutnya, penelitian oleh Zeinali et al., (2019) yang menyampaikan hasil penelitian oleh Hemshekhar et al., (2012) yang meneliti mengenai konstituen crocin pada saffron menemukan bahwa pemberian crocin $(20 \mathrm{mg} / \mathrm{kg})$ efektif dalam menetralkan peningkatan kadar HAase serum dibandingkan dengan ibuprofen. Pada artritis, HAase akan meningkat yang akan menyebabkan degradasi dari komponen extracellular matrix (ECM) yang yakni termasuk didalamnya adalah type II collagen, hyaluronan (HA), dan aggrecan. Peningkatan HAase tersebut yang menghasilkan terjadinya degenerasi articular cartilage yang berat. Degradasi HA akibat peningkatan HAase kemudian akan mengarahkan kepada generasi proinflamasi oligosakarida HA. Oligosakarida HA tersebut merupakan ligan endogen untuk reseptor CD44 dan TLR-4 dan dapat menginduksi kondrosit artikular dan fibroblas kartilage untuk mensekresi sitokin proinflamasi yakni TNF- $\alpha$. Stimulasi CD44 dan TLR-4 tersebut juga akan memicu berbagai jalur inflamasi yang berujung dengan aktivasi NF-kB yang merupakan penanggung jawab atas ekspresi mediator inflamasi dan MMP. Oleh karena itu, penghambatan HAase tidak hanya akan mengurangi degradasi HA tetapi juga mengurangi pelepasan sitokin inflamasi (12).

Tak hanya itu, kandungan lainnya dari saffron yakni crocin, oleh Liu et al., 2018 dilaporkan 
memiliki efek dalam menurunkan kadar TNF- $\alpha$ pada model tikus CIA (collagen induced arthritis) dengan pemberian dosis $40 \mathrm{mg} / \mathrm{kg}$ sebagai dosis tertinggi yang diduga terjadi akibat efek dari kandungan saffron yakni crocin yang dapat menurunkan ekspresi mRNA dari sitokin proinflamasi. Tak hanya itu, pada penelitian tersebut, juga didapatkan bahwa crocin memiliki kemampuan untuk menurunkan matrix metalloproteinase (MMP) yang merupakan salah satu enzim yang bertanggung jawab terhadap terjadinya degradasi dari extracellular matrix molecules. Hal ini dapat dimengerti mengingat bahwa TNF- $\alpha$ merupakan sitokin yang menstimulasi fibroblast-like synoviocytes (FLSs) untuk melepaskan cathepsin, aggrecanases, dan matrix metalloproteinase (MMP). Sehingga, saat TNF- $\alpha$ dihambat oleh crocin, maka akan menghambat produksi MMP (9).

Crocin juga dalam penelitian oleh Wang et al., 2020 didapati memiliki efek lainnya terhadap Wnt5a/ $\beta$ yang kemudian menunjukkan adanya penurunan TNF- $\alpha$. Hal tersebut diduga terjadi karena salah satu efek lainnya dari crocin ialah mampu menghambat $\mathrm{Wnt} 5 \mathrm{a} / \beta$ yang merupakan sistem transduksi sinyal yang kompleks diantara sel yang memiliki peran penting dalam respon inflamasi yang salah satunya yakni berperan dalam meningkatkan regulasi dari ekspresi faktor proinflamasi penting seperti IL-1 $\beta$, IL-6, dan TNF- $\alpha$ (16). Sebelumnya, pada tahun 2018, terdapat penelitian oleh Arzi et al. yang meneliti efek crocin dan crocetin didalam jalur Wnt/ $\beta$-Catenin pada sel kanker payudara dengan hasil bahwa efek yang dihasilkan oleh crocin pada model yang berhubungan dengan metastasis adalah karena penghambatan terhadap jalur Wnt/ $\beta$-Catenin (22)

Sedangkan itu, untuk kandungan safranal yang berada didalam saffron belum ditemukan penelitian dengan model artritis reumatoid, namun ditemukan terdapat pada beberapa studi lainnya yakni penelitian oleh Bharti S., Golechha M., Kumari S., et al. menyatakan bahwa safranal pada saffron dapat menurunkan level TNF- $\alpha$ secara signifikan diakibatkan dari efek sito-protektif dari safranal. Penelitian lainnya oleh Lertnimitphun et al., 2019, pada tikus kolitis yang diinduksi DSS, didapatkan safranal pada dosis $500 \mathrm{mg} / \mathrm{kg}$ dapat menurunkan produksi sitokin TNF- $\alpha$ dibandingkan dengan grup DSS tanpa terapi (23). Penelitian lainnya oleh Hazman dan Ovali, 2015 menyatakan bahwa pada model tikus yang diberikan diet tinggi lemak dan diinduksi dengan STZ ditemukan bahwa pemberian safranal yang merupakan salah satu komponen dari saffron selama 4 minggu dapat menurunkan inflamasi dengan menurunkan kadar $\mathrm{TNF}-\alpha$ pada plasma dan jaringan pankreas (24).
Dalam beberapa tahun terakhir terdapat banyak penelitian lainnya mengenai efek saffron dan juga konstituen di dalam nya yang menunjukkan bahwa saffron (Crocus sativus) memiliki berbagai keuntungan terhadap berbagai model penyakit antara lain iskemia-perfusi pada renal dan jantung, alzheimer's disease, penyakit digestivus, colitis, fibrosis hepar, penyakit degenerasi, nyeri neuropati, ulkus pada usus halus, dan model lainnya.

\section{SIMPULAN}

Berdasarkan hasil analisis jurnal yang telah dilakukan, dapat disimpulkan bahwa saffron (Crocus sativus) dan komponen di dalamnya (crocin, crocetin, safranal, dan lain lain) dapat secara efektif menurunkan dan mengatur kadar TNF- $\alpha$ yang merupakan penyebab terjadinya inflamasi dan proses destruksi tulang pada model artritis reumatoid dan memiliki kemungkinan untuk menjadi terapi yang digunakan dalam artritis reumatoid pada manusia.

\section{SIMPULAN}

Berdasarkan hasil analisis jurnal yang telah dilakukan, dapat disimpulkan bahwa saffron (Crocus sativus) dan komponen di dalamnya (crocin, crocetin, safranal, dan lain lain) dapat secara efektif menurunkan dan mengatur kadar TNF- $\alpha$ yang merupakan penyebab terjadinya inflamasi dan proses destruksi tulang pada model artritis reumatoid dan memiliki kemungkinan untuk menjadi terapi yang digunakan dalam artritis reumatoid pada manusia.

\section{DAFTAR PUSTAKA}

1. Guo Q, Wang Y, Xu D, Nossent J, Pavlos NJ, Xu J. Rheumatoid arthritis: pathological mechanisms and modern pharmacologic therapies. Bone Res. 2018;6(1):15.

2. Marshall AA, Zaccardelli A, Yu Z, Prado MG, Liu X, Miller Kroouze R, et al. Effect of communicating personalized rheumatoid arthritis risk on concern for developing RA: A randomized controlled trial. Patient Educ Couns. 2019;102(5):976-83.

3. Chabib L, Ikawati Z, Martien R, Ismail H. Terapi Farmakologi, Potensi Kurkumin dan Analognya, serta Pengembangan Sistem Nanopartikel. J Pharmascience. 2016;1(5):25-31.

4. Elsi M. Gambaran faktor dominan pencetus arthritis rheumatoid di wilayah kerja puskesmas danguang danguang payakumbuh tahun 2018. MENARA Ilmu. 2018;XII(8):98-106.

5. Rudan I, Sidhu S, Papana A, Meng S-J, 
Xin-Wei Y, Wang W, et al. Prevalence of rheumatoid arthritis in low- and middleincome countries: A systematic review and analysis. J Glob Health. 2015;5(1):010409.

6. Rathore B, Jaggi K, Thakur SK, Mathur A, Mahdi F. Anti-inflammatory activity of crocus sativus extract in experimental arthritis. Int J Pharm Sci Res. 2015;6(4):1473-8.

7. Ghaffari S, Roshanravan N. Saffron; An updated review on biological properties with special focus on cardiovascular effects. Biomed Pharmacother. 2019;109(May 2018):21-7.

8. Li X, Jiang C, Zhu W. Crocin reduces the inflammation response in rheumatoid arthritis. Biosci Biotechnol Biochem. 2017;81(5):891-8.

9. Liu W, Sun Y, Cheng Z, Guo Y, Liu P, Wen Y. Crocin exerts anti-inflammatory and anti-arthritic effects on type II collagen-induced arthritis in rats. Pharm Biol. 2018;56(1):209-16.

10. Siswanto S. Systematic Review Sebagai Metode Penelitian Untuk Mensintesis Hasil-Hasil Penelitian (Sebuah Pengantar). Bul Penelit Sist Kesehat. 2012;13(4 Okt).

11. Ashrafi M, Afsar Z, Erjaee H, Nazifi S. The effects of saffron (crocus sativus) aqueous extract on TNF- $\alpha$ levels in liver, kidney, and lens tissues of diabetic rats. Turkish J Endocrinol Metab. 2018;22(4):217-24.

12. Hemshekhar M, Santhosh MS, Sunitha K, Thushara RM, Kemparaju K, Rangappa $\mathrm{KS}$, et al. Biochimie A dietary colorant crocin mitigates arthritis and associated secondary complications by modulating cartilage deteriorating enzymes, in $\mathrm{fl}$ ammatory mediators and antioxidant status. Biochimie. 2012;94(12):2723-33.

13. Jasaputra DK, Santosa S, editors. Metodologi Penelitian Biomedis. Edisi 2. Bandung: PT. Danamartha Sejahtera Utama; 2008.

14. Zeinali M, Zirak MR, Rezaee SA, Karimi G, Hosseinzadeh H. Immunoregulatory and anti-inflammatory properties of Crocus sativus (Saffron) and its main active constituents: A review. Iran J Basic Med Sci. 2019;22(4):334-44.

15. Li Y, Kakkar R, Wang J. In vivo and in vitro Approach to Anti-arthritic and Antiinflammatory Effect of Crocetin by Alteration of Nuclear Factor-E2-Related Factor 2/hem Oxygenase (HO)-1 and NF$\kappa \mathrm{B}$ Expression. Front Pharmacol. 2018 Dec;9.

16. Wang J-F, Xu H-J, He Z-L, Yin Q, Cheng W. Crocin Alleviates Pain Hyperalgesia
inAIA Rats by Inhibiting the Spinal Wnt5a/ $\beta$-Catenin Signaling Pathway and Glial Activation. Neural Plast. 2020;2020:4297483.

17. Kim EY, Moudgil KD. Immunomodulation of autoimmune arthritis by proinflammatory cytokines. Cytokine. 2017;98(April):87-96.

18. Song L, Kang C, Sun Y, Huang W, Liu W, Qian Z. Crocetin Inhibits

Lipopolysaccharide-Induced Inflammatory Response in Human Umbilical Vein Endothelial Cells. Cell Physiol Biochem. 2016;40(3-4):443-52.

19. Li S, Liu X, Lei J, Yang J, Tian P, Gao Y. Crocin Protects Podocytes Against Oxidative Stress and Inflammation Induced by High Glucose Through Inhibition of NF- $\kappa$ B. Cell Physiol Biochem. 2017;42(4):1481-92.

20. Amin A, Hamza AA, Bajbouj K, Ashraf SS, Daoud S. Saffron: A potential candidate for a novel anticancer drug against hepatocellular carcinoma. Hepatology. 2011;54(3):857-67.

21. Abedimanesh N, Motlagh B, Abedimanesh S, Bathaie SZ, Separham A, Ostadrahimi A. Effects of crocin and saffron aqueous extract on gene expression of SIRT1, AMPK, LOX1, NF- $\kappa$ B, and MCP-1 in patients with coronary artery disease: $\mathrm{A}$ randomized placebo-controlled clinical trial. Phyther Res. 2019;(November):1-9.

22. Arzi L, Riazi G, Sadeghizadeh M, Hoshyar R, Jafarzadeh N. A Comparative Study on Anti-Invasion, Antimigration, and Antiadhesion Effects of the Bioactive Carotenoids of Saffron on 4T1 Breast Cancer Cells Through Their Effects on Wnt/ $\beta$-Catenin Pathway Genes. DNA Cell Biol. 2018;37(8):697-707.

23. Lertnimitphun P, Jiang Y, Kim N, Fu W, Zheng C, Tan H, et al. Safranal alleviates dextran sulfate sodium-induced colitis and suppresses macrophage-mediated inflammation. Front Pharmacol. 2019;10.

24. Islam MA, Alam F, Solayman M, Khalil MI, Kamal MA, Gan SH. Dietary Phytochemicals: Natural Swords Combating Inflammation and OxidationMediated Degenerative Diseases. Oxid Med Cell Longev. 2016;2016:5137431 